\title{
Impact of Covid-19 Coronavirus Infection Pandemic on Financial Stability of Russian Black Metals Companies
}

\author{
Dolgikh Yu.A.* Smorodina E.A. Slepukhina Yu.E.
}

Ural Federal University named after the first President of Russia B.N. Yeltsin, Ekaterinburg 620144, Russian Federation *Corresponding author. Email: rimdm@rambler.ru

\begin{abstract}
The relevance of this study is due, on the one hand, to the high level of significance of the ferrous metallurgy sector for the Russian economy and, on the other hand, to the presence of serious threats to the sustainable functioning of the investigated industry in the medium term due to the impact of the COVID-19 pandemic. The article analyzes the dynamics and structure of Russian production of the main ferrous metallurgy products in 2007-2018; identifies key risk factors to ensure the financial stability of Russian metallurgical holdings in the medium term; assesses the financial stability of seven largest metallurgical companies in the dynamics of 3, 4 quarters of 2019 and 1, 2 quarters of 2020 to determine the degree of negative impact of the pandemic on their financial position. In the context of the identified probable negative trends in the functioning of Russian ferrous metallurgical companies, the authors have formulated the main directions of measures to improve their financial stability.
\end{abstract}

Keywords: financial stability, COVID-19 pandemic, Russian companies, ferrous metallurgy, anti-crisis

measures

\section{INTRODUCTION}

The "ferrous metallurgy" sector, which includes directly metallurgical production (ferrous metals and pipes), as well as mining and processing of ferrous metal ores, is the basic industry of the economy, an instrument of national security, a source of employment and income for a significant part of the population not only in Russia but also in many other developed countries.

The share of ferrous metallurgy in the Russian GDP is about $1.5 \%$, in industrial production - about $8 \%$, in exports - $6 \%$. As a consumer of products and services of natural monopolies, ferrous metallurgy uses $5.3 \%$ of electricity, more than $8 \%$ of natural gas of the total domestic consumption in Russia, its share in freight rail transportation is $15 \%$. At present, Russia is the world's fifth-largest producer of steel (after China, Japan, India, and the USA), second largest producer of steel pipes (after China), third-largest exporter of metal products (after China and Japan), fifth-largest producer of commercial iron ore (after China, Australia, Brazil, and India) [1].

Ferrous metallurgy is one of the few processing industries in Russia whose production capacity in a number of key steel products significantly exceeds the capacity of the domestic market, thus determining the export orientation of the industry. Demand for ferrous metallurgy products is observed in almost equal proportions on the domestic and foreign markets. About half of export metallurgical products are semi-finished products. In particular, export volumes of semi-finished products made of unalloyed steel and iron are consistently high [2].
The Russian ferrous metallurgy sector includes about one and a half thousand enterprises, with the industry being highly concentrated. This is evidenced by the fact that more than $80 \%$ of the total output of steel products in Russia falls on just 9 vertically integrated corporate groups. They include such metallurgical companies as JSC MC Metalloinvest, PJSC Magnitogorsk Iron and Steel Works (PJSC MMK), PJSC Novolipetsk Iron and Steel Works (PJSC NLMK) PJSC Severstal, PJSC Mechel, JSC Evraz Holding as well as pipe companies PJSC Pipe Metallurgical Company (PJSC TMK), JSC United Metallurgical Company, JSC Chelyabinsk Tube Rolling Plant Group (JSC ChTPZ).

These companies, being export-oriented, are among the key players in their respective global commodity markets. In this connection, the sustainability of their functioning and development plays a significant role in ensuring the diversification of the Russian economy and strengthening its competitive position in the global market.

In 2020, Russian iron and steel companies faced a serious threat to their financial stability, manifested in a significant decline in demand for iron ore and steel products on the global and domestic Russian markets amid a decline in economic activity due to restrictions caused by the coronavirus pandemic COVID-19.

The most crisis situation was observed in the second quarter of 2020 . World GDP fell by $6.9 \%$ over this period compared to the second quarter of 2019. This was also preceded by a 1.4 percent decline in global GDP in the first quarter of 2020 compared to the same period in 2019. Developed countries suffered most from the recession: GDP in this group of countries fell by 13.6 percent in the second quarter of 2020 , compared to the second quarter of 
2019 , after falling by 1.1 percent in the first quarter of 2020 compared to the same period in 2019 [3].

Global industrial production in the second quarter of 2020 decreased by $9.4 \%$ compared to the second quarter of 2019. The first quarter of 2020 also saw a decline in global industrial output, but at a much lower rate (4.6\% compared to the same period of the previous year). In developed countries, the decline in industrial production was even deeper: $-14.2 \%$ in the second quarter of 2020 compared to the same period in 2019. The sharpening decline in economic activity in the key metal-consuming sectors of the global economy has led to a decline in the global consumption of rolled metal products to a minimum level over the past decade. The decline in global net visible consumption of flat steel products in the second quarter of 2020 is estimated at $18.3 \%$ compared to the first quarter of 2020, including in North America: $-25.9 \%$; in the EU: 18.2\%; in Asia: $-16.7 \%$; in Central and South America: $12,3 \%$ [4].

On the domestic Russian market, the most intense contraction of economic activity was also observed in April-May 2020. According to the estimates of the Ministry of Economic Development of Russia, in April the decline in GDP was 12\% compared to April 2019; in May it was slightly lower: $-10.9 \%$ compared to the same period in 2019. On the whole, over the period from January to May 2020, the decline in GDP was 3.7\% as compared to the same period of the previous year [5].

As for the Russian industrial production, in May 2020 its volume decreased by $9.6 \%$, in April - by $6.6 \%$ compared to the same periods of 2019. In the first five months of 2020, the decline in industrial production in Russia was $2.4 \%$ [6]. As a result of these destructive trends, the decline in apparent consumption of rolled steel in Russia in January-May 2020 was 7\% compared with the same period last year [7].

Such a significant reduction in demand for iron ore raw materials and metal products was a serious challenge for Russian ferrous metallurgical companies in terms of ensuring their financial stability. The situation is also aggravated by a number of intra-industry problems. This work is devoted to the study of the impact of the COVID19 pandemic on the financial stability of Russian steel companies in the context of existing systemic intraindustry and external risk factors, as well as identifying the main directions of anti-crisis measures.

\section{RESEARCH METHODS}

The study of the current state of the Russian ferrous metallurgy should be started by analyzing the dynamics of the production of its main products. The period under analysis covers 2007-2018 (Table 1).
The data presented in Table 1 indicate the cyclical nature of the dynamics of Russian production of the main ferrous metallurgy products in the analyzed period. This is due to the fact that demand for the products of metallurgical companies is affected by global cycles of economic activity. The construction industry (36\%) and pipe production $(23 \%)$ account for the bulk of the steel consumption drivers. The rest falls on the production of metalware and metal structures (12\%), machinery and equipment $(9 \%)$, household appliances $(4 \%)$, automotive $(3 \%)$ and other consumer sectors (13\%) [10].

This structure of ferrous metal consumption drivers largely explains cyclical fluctuations in metallurgical production volumes: recession during the global financial crisis of 2008-2009, then a slow recovery and approaching precrisis volumes in 2011-2012, then another decline in production volumes in 2013, followed by another slight growth and stagnation in the period 2014-2017. The growth of ferrous metallurgy output in 2018 was driven by increased domestic demand in connection with national projects in Russia.

In addition to the unstable level of demand for ferrous metals, it is necessary to note one more significant negative factor limiting the potential for the growth of production volumes on the part of Russian ferrous metallurgy enterprises is the effect of sanctions, trade barriers, which actually close a number of foreign markets for Russian metallurgical companies. As of the beginning of 2020, Russian steel companies are subject to about fifty different restrictive non-tariff regulation measures. The most problematic markets for Russian exports of metal products are the USA, the European Union and Mexico. A significant number of restrictions were introduced in the period 2014-2016. [11].

Thus, the medium-term prospects for Russian steel companies are unfavorable due to the following key factors:

1. Global and Russian economic decline due to COVID-19 pandemic in 2020 and slowdown of national economy growth in 2021-2022 (see Tables 2, 3);

2. Effects of numerous trade barriers and sanctions against steel products exported from Russia;

Lack of systematic long-term drivers for growth in demand for steel products on the domestic Russian market. In the period up to 2024 , of course, we can expect a slight increase in domestic demand for ferrous metallurgy products due to the implementation of national projects in Russia, as well as the Integrated Plan for modernization and expansion of mainline infrastructure. However, these are point growth drivers, the impact of which is limited by the timing of these projects (until 12/31/2024). In addition, it is not ruled out that the financing of a number of national projects may be adjusted (reduced) due to a stable deficit of the federal budget of Russia in the near term. 
Table 1: Dynamics of Russian production of main ferrous metallurgy products in 2007-2018, mln tons

\begin{tabular}{|l|c|c|c|c|c|c|c|c|c|c|c|c|}
\hline \multicolumn{1}{|c|}{ Products } & $\mathbf{2 0 0 7}$ & $\mathbf{2 0 0 8}$ & $\mathbf{2 0 0 9}$ & $\mathbf{2 0 1 0}$ & $\mathbf{2 0 1 1}$ & $\mathbf{2 0 1 2}$ & $\mathbf{2 0 1 3}$ & $\mathbf{2 0 1 4}$ & $\mathbf{2 0 1 5}$ & $\mathbf{2 0 1 6}$ & $\mathbf{2 0 1 7}$ & $\mathbf{2 0 1 8}$ \\
\hline Iron Ores & 104.9 & 101.6 & 92.5 & 102.4 & 105.6 & 109.6 & 110.7 & 106.3 & 106.3 & 104 & 105.4 & 106.5 \\
\hline Cast iron & 51.5 & 48.3 & 44.0 & 48.0 & 48.0 & 50.5 & 49.9 & 51.5 & 52.4 & 51.9 & 52.1 & 51.8 \\
\hline Steel & 72.4 & 68.7 & 59.4 & 66.8 & 681 & 70.4 & 68.9 & 70.5 & 69.4 & 69.8 & 73.2 & 74.4 \\
\hline $\begin{array}{l}\text { Finished } \\
\text { rolled } \\
\text { ferrous } \\
\text { metals }\end{array}$ & 59.6 & 56.7 & 50.8 & 55.0 & 56.5 & 60.0 & 59.2 & 61.2 & 60.4 & 60.5 & 60.5 & 61,7 \\
\hline Steel pipes & 10.9 & 9.7 & 9.0 & 9,2 & 10.0 & 9.7 & 10,1 & 11,3 & 11.4 & 10.4 & 11.8 & 12.2 \\
\hline
\end{tabular}

Compiled by the authors based on sources $[8,9]$.

Table 2: World economic development forecasts for 2020 [12]

\begin{tabular}{|c|c|}
\hline $\begin{array}{c}\begin{array}{c}\text { Organization } \\
\text { (subject of prediction) }\end{array} \\
\end{array}$ & $\begin{array}{c}\begin{array}{c}\text { Forecast change (growth rate) } \\
\text { world GDP in } 2020, \%\end{array} \\
\end{array}$ \\
\hline $\begin{array}{l}\text { National Research University Higher School of } \\
\text { Economics }\end{array}$ & ( \\
\hline International Monetary Fund (IMF) & $-3 \%$ \\
\hline Scope Rating & $\begin{array}{l}-3.3 \% \text { (optimistic scenario) } \\
-8.8 \% \text { (probable scenario) } \\
-11.3 \% \text { (pessimistic scenario) }\end{array}$ \\
\hline McKinsey & $\begin{array}{l}-3.8 \% \text { (optimistic scenario) } \\
-10.2 \% \text { (pessimistic scenario) }\end{array}$ \\
\hline Bloomberg & $-4.5 \%$ \\
\hline JP Morgan & $-5.2 \%$ \\
\hline
\end{tabular}

Table 3 Forecasts of the Russian economy development for the period of 2020-2022 [12]

\begin{tabular}{|l|c|c|c|}
\hline \multirow{2}{*}{\begin{tabular}{c}
\multirow{2}{*}{$\begin{array}{c}\text { Organization } \\
\text { (subject of prediction) }\end{array}$} \\
\cline { 2 - 4 }
\end{tabular}} & $\mathbf{2 0 2 0}$ & $\mathbf{2 0 2 1} \begin{array}{c}\text { Forecast change (growth rate) } \\
\text { Russian GDP, \% of previous year }\end{array}$ & $\mathbf{2 0 2 2}$ \\
\hline Central Bank of Russia & $(-4 \%)-(-6 \%)$ & $2.8 \%-4.8 \%$ & $1.5 \%-3.5 \%$ \\
\hline World Bank & $(-1.0 \%)-(-2.2 \%)$ & $1.6 \%$ & $1.8 \%$ \\
\hline International Monetary Fund (IMF) & $-5.5 \%$ & $3.5 \%$ & - \\
\hline $\begin{array}{l}\text { Organization for Economic } \\
\begin{array}{l}\text { Cooperation and Development } \\
\text { (OECD) }\end{array}\end{array}$ & $1.2 \%$ & $1.3 \%$ & - \\
\hline Consensual forecast & $\mathbf{( - 2 . 5 \% ) - ( - 3 . 1 \% )}$ & $\mathbf{2 . 3 \% - 2 . 7 \%}$ & - \\
\hline
\end{tabular}

In the context of the impact of these factors, we investigate the dynamics of the level of financial stability of Russian ferrous metallurgical companies in terms of 3.4 quarters of 2019 (period before the pandemic) and 1.2 quarters of 2020 (crisis period).

By financial stability of a company the authors understand its ability to function and develop in a changing business environment, achieving its goals with a given interval of possible deviations, and to fulfill its obligations on the basis of effective formation, distribution, and use of financial resources [11].

A deep and comprehensive assessment of financial stability of the company should be carried out on the basis of the author's methodology described in "Development of methodological tools assessment of financial stability of enterprise" [13]. However, its application is possible if the main forms of the company's annual financial statements under RAS are available (balance sheet; statement of financial results; cash flow statement).

According to the Russian legislation, interim financial statements of the organization (for the quarter and half of the year) under RAS include only two mandatory forms balance sheet and financial results report. In this regard, the rapid assessment of the financial stability of Russian metallurgical companies for 3, 4 quarters of 2019 and 1,2 quarters of 2020, assuming the use of these forms of interim financial statements of companies, is proposed to be based on the calculation of the following financial and economic indicators:

- current liquidity ratio; 
- quick liquidity ratio;

- absolute liquidity ratio;

- financial independence ratio;

- financial sustainability ratio;

- net working capital ratio;

- return on assets;

- return on equity.

The information base for calculation of the first six coefficients is the balance sheet, where the information is reflected at the end of each reporting period, so it is possible to compare the values of these coefficients in the dynamics of the above four quarters. Profitability indicators are calculated using the report on financial results, where information is reflected for the reporting period - therefore, the basis for comparison of profitability indicators for the 1st quarter of 2020, 1st half of 2020 are the same periods of 2019 .

The analyzed sample of Russian iron and steel companies includes 7 out of 9 corporate groups (holdings) listed in the introduction: JSC Metalloinvest Management Company, PJSC MMK, PJSC NLMK, PJSC Severstal, PJSC Mechel, PJSC TMK, JSC ChTPZ. Such companies as Evraz Holding and United Metallurgical Company are excluded from the analysed sample because they do not make their interim financial statements publicly available. The results of the analysis are shown in tables 4, 5 .

Table 4: Dynamics of financial ratios (indicators of financial stability) of Russian ferrous metallurgy companies in the period of 3, 4 quarters 2019 - 1, 2 quarters 2020.

\begin{tabular}{|c|c|c|c|c|}
\hline \multirow[b]{2}{*}{ Company name } & \multicolumn{4}{|c|}{ Indicator value } \\
\hline & $\begin{array}{c}\text { As of } \\
09 / 30 / 2019\end{array}$ & $\begin{array}{c}\text { As of } \\
12 / 31 / 2019\end{array}$ & $\begin{array}{c}\text { As of } \\
03 / 31 / 2020\end{array}$ & $\begin{array}{c}\text { As of } \\
06 / 30 / 2020\end{array}$ \\
\hline \multicolumn{5}{|c|}{ Current liquidity ratio (standard $\geq 2$ ) } \\
\hline PJSC MMK & 2.03 & 1.66 & 2.03 & 1.93 \\
\hline JSC MC Metalloinvest & 1.28 & 20.11 & 0.359 & 10.71 \\
\hline PJSC Severstal & 1.67 & 1.49 & 2.06 & 1.09 \\
\hline PJSC NLMK & 1.76 & 1.68 & 1.58 & 1.44 \\
\hline PJSC Mechel & 0.37 & 0.26 & 0.31 & 0.26 \\
\hline PJSC TMK & 0.98 & 1.05 & 1.50 & 1.52 \\
\hline JSC CHTPZ & 1.23 & 0.98 & 1.09 & 1.30 \\
\hline \multicolumn{5}{|c|}{ Ratio of quick liquidity (standard $\geq 1$ ) } \\
\hline PJSC MMK & 1.36 & 1.13 & 1.40 & 1.28 \\
\hline JSC MC Metalloinvest & 1.28 & 20.11 & 0.359 & 10.71 \\
\hline PJSC Severstal & 1.1 & 1.03 & 1.54 & 0.72 \\
\hline PJSC NLMK & 1.34 & 1.21 & 1.26 & 1.11 \\
\hline PJSC Mechel & 0.36 & 0.26 & 0.30 & 0.25 \\
\hline PJSC TMK & 0.94 & 1.01 & 1.47 & 1.50 \\
\hline JSC CHTPZ & 0.84 & 0.81 & 0.91 & 1.07 \\
\hline \multicolumn{5}{|c|}{ Absolute liquidity ratio (standard $\geq 0.2$ ) } \\
\hline PJSC MMK & 0.75 & 0.71 & 0.83 & 0.61 \\
\hline JSC MC Metalloinvest & 0.33 & 11.81 & 0.21 & 1.95 \\
\hline PJSC Severstal & 0.73 & 0.60 & 0.95 & 0.32 \\
\hline PJSC NLMK & 0.30 & 0.30 & 0.72 & 0.55 \\
\hline PJSC Mechel & 0.16 & 0.12 & 0.12 & 0.001 \\
\hline PJSC TMK & 0.22 & 0.22 & 0.51 & 0.33 \\
\hline JSC CHTPZ & 0.20 & 0.39 & 0.46 & 0.69 \\
\hline \multicolumn{5}{|c|}{ Financial Independence Ratio (standard 0.5-0.7) } \\
\hline PJSC MMK & 0.67 & 0.62 & 0.64 & 0.65 \\
\hline JSC MC Metalloinvest & 0.50 & 0.57 & 0.03 & 0.51 \\
\hline PJSC Severstal & 0.34 & 0.36 & 0.35 & 0.34 \\
\hline PJSC NLMK & 0.56 & 0.56 & 0.50 & 0.52 \\
\hline PJSC Mechel & 0.04 & 0.03 & 0.03 & 0.03 \\
\hline PJSC TMK & 0.14 & 0.14 & 0.15 & 0.18 \\
\hline JSC CHTPZ & 0.19 & 0.16 & 0.14 & 0.16 \\
\hline \multicolumn{5}{|c|}{ Financial sustainability ratio (standard $\geq 0.8$ ) } \\
\hline PJSC MMK & 0.80 & 0.76 & 0.81 & 0.82 \\
\hline JSC MC Metalloinvest & 0.86 & 0.99 & 0.45 & 0.94 \\
\hline
\end{tabular}




\begin{tabular}{|l|c|c|c|c|} 
PJSC Severstal & 0.78 & 0.78 & 0.84 & 0.75 \\
\hline PJSC NLMK & 0.76 & 0.78 & 0.74 & 0.74 \\
\hline PJSC Mechel & 0.85 & 0.80 & 0.77 & 0.81 \\
\hline PJSC TMK & 0.46 & 0.47 & 0.51 & 0.55 \\
\hline JSC CHTPZ & 0.66 & 0.55 & 0.59 & 0.63 \\
\hline \multicolumn{2}{|c|}{ Working capital adequacy ratio of own sources of financing (ratio $\geq 0.1)$} \\
\hline PJSC MMK & 0.17 & 0.04 & 0.09 & 0.02 \\
\hline JSC MC Metalloinvest & -1.87 & -1.92 & -3.90 & 0.28 \\
\hline PJSC Severstal & -0.77 & -0.94 & -0.96 & -1.45 \\
\hline PJSC NLMK & -0.06 & -0.16 & -0.20 & -0.28 \\
\hline PJSC Mechel & -16.33 & -17.56 & -12.89 & -18.90 \\
\hline PJSC TMK & -0.61 & -0.56 & -0.17 & -0.18 \\
\hline JSC CHTPZ & -0.09 & -0.90 & -0.91 & -0.75 \\
\hline
\end{tabular}

Compiled by the authors

Table 5: Comparative analysis of return on assets and equity of Russian ferrous metallurgy companies in Q1 and H1 2019-2020 (in Russian)

\begin{tabular}{|l|c|c|c|c|}
\hline \multirow{2}{*}{ Company name } & \multicolumn{4}{c|}{ Indicator value } \\
\cline { 2 - 5 } & $\begin{array}{c}\text { In the 1st quarter } \\
\mathbf{2 0 2 0}\end{array}$ & $\begin{array}{c}\text { For the 1st } \\
\text { quarter 2019 }\end{array}$ & $\begin{array}{c}\text { In the first half } \\
\text { of the year } \\
\mathbf{2 0 2 0}\end{array}$ & $\begin{array}{c}\text { In the first half of } \\
\text { the year } \\
\mathbf{2 0 1 9}\end{array}$ \\
\hline \multicolumn{3}{|c|}{ Return on assets (calculated by net profit), \% } \\
\hline PJSC MMK & 2.63 & 3.53 & 5.21 & 8.57 \\
\hline JSC MC Metalloinvest & -5.69 & -1.43 & 54.89 & 25.96 \\
\hline PJSC Severstal & 0.72 & 5.24 & 6.23 & 8.01 \\
\hline PJSC NLMK & -1.39 & 3.06 & 5.57 & 9.20 \\
\hline PJSC Mechel & -0.27 & 0.22 & -0.14 & -0.13 \\
\hline PJSC TMK & 4.12 & 3.30 & 6.21 & 5.27 \\
\hline JSC CHTPZ & -1.65 & 0.22 & 1.89 & 0.75 \\
\hline & Return on equity (calculated by net profit), \% & \multicolumn{2}{c|}{} \\
\hline PJSC MMK & 4.16 & 5.37 & -3.06 & 13.44 \\
\hline JSC MC Metalloinvest & -19.65 & -3.77 & 173.47 & 58.89 \\
\hline PJSC Severstal & 2.01 & 11.32 & 18.01 & 19.68 \\
\hline PJSC NLMK & -2.62 & 5.08 & 10.97 & 16.42 \\
\hline PJSC Mechel & -8.59 & 5.96 & -4.83 & -4.05 \\
\hline PJSC TMK & 28.57 & 25.86 & 37.80 & 40.14 \\
\hline JSC CHTPZ & $-11,17$ & 0.91 & 12.76 & 3.44 \\
\hline
\end{tabular}

Compiled by the authors

\section{RESEARCH RESULTS}

The following main conclusions can be drawn from the study:

1. During the crisis period (Q1, Q2 2020) the actual values of current liquidity ratio reflecting the degree of coverage of short-term liabilities by current assets do not correspond to the normative value of 4 of 7 analyzed companies. At the same time, the remaining three companies (PJSC MMK, JSC MC Metalloinvest, PJSC Severstal) meet the actual value of the current liquidity ratio only in one quarter, i.e. it is not a trend. It should be noted that this situation is also typical for the pre-crisis period (3, 4 quarters of 2019), in which $100 \%$ of the sample does not observe compliance of the current liquidity ratio to the norm. As to the general character of dynamics of the given indicator change, at the majority of the analyzed companies, it is not unequivocal. Only PJSC NLMK's current liquidity ratio has been steadily decreasing over the entire period under analysis.

2. A more positive trend has been identified with regard to the actual values of the quick liquidity ratio reflecting the extent to which short-term liabilities are covered by cash, short-term investments, and accounts receivable. Compliance with their normative value during the whole period under analysis is typical for three companies: PJSC MMK, PJSC Severstal, PJSC NLMK. The rest of the sample did not show a clear downward trend during the pandemic crisis period. 
3. In terms of the absolute liquidity ratio, which characterizes the company's ability to repay its short-term liabilities with the most liquid assets (cash and short-term financial investments), an even more favorable situation is observed. Throughout the whole analyzed period, the actual values of the given factor correspond to the norm at 6 of 7 companies. The only exception is Mechel PJSC. Again, there is no tendency to decrease the values of the absolute liquidity ratio in Q1 and Q2 2020.

4. As for the financial independence ratio reflecting the share of equity in the total capital structure of the company, the analyzed sample shows an unfavorable picture. The share of shareholders' equity exceeds the normative mark of $50 \%$ only at two companies: PJSC MMK and PJSC NLMK. Other metallurgical holdings essentially depend on borrowed sources of financing of their activity, especially it concerns PJSC Mechel, at which share of borrowed capital in the analyzed period makes 96-97\%. In general, there is no trend for the companies studied to increase their share of borrowed funds during the pandemic.

5. A similar negative situation can be observed with regard to the financial stability ratio, showing what part of the company's property is financed by sustainable sources (own funds and long-term liabilities). None of the analyzed metallurgical companies differs by stable conformity of actual values of the given indicator to the norm. At the same time, the three holdings (JSC MC Metalloinvest, PJSC NLMK, PJSC Mechel) have seen a decline in the share of sustainable sources of financing in Q1 2020 as compared to Q4 2019. This was particularly expressive in respect of JSC MC Metalloinvest, where the above indicator has almost halved (from 0.99 in Q4 2019 to 0.45 in Q1 2020).

6 . The actual values of the working capital adequacy ratio, which characterizes how much of the company's current assets are financed from its own sources, also testify to the unstable financial condition of Russian metallurgical holdings. Most of them, with the exception of PJSC MMK, have a complete lack of own working capital both in the pre-crisis period of 2019 and during the pandemic.

7. Comparative analysis of ROA and equity values of metallurgical companies in the context of the first quarter and first half of 2019-2020 clearly demonstrates the impact of the pandemic on the efficiency of the investigated business. In the first quarter of 2020, the profitability of assets and capital decreased in six out of seven companies compared to the same period in 2019 (only PJSC TMK is an exception). In the first half of 2020 the dynamics is also negative on the whole: as compared to the first half of 2019, four holdings (PJSC MMK, PJSC Severstal, PJSC NLMK, PJSC Mechel) have lower return on assets; five holdings (PJSC MMK, PJSC Severstal, PJSC NLMK, PJSC Mechel, PJSC TMK) have lower return on equity.

Summarizing the results of the study, it should be noted that the impact of the COVID-19 pandemic on Russian steel companies in the first half of 2020 is mainly expressed in a decrease in profitability indicators, which is due to a significant decrease in revenues and, consequently, in net profit for most companies (Figures 1, 2). A striking exception is JSC Metalloinvest Management Company, which during the crisis period of the pandemic, on the contrary, has seen a significant increase in both revenues and net profit, this is explained by the results of the holding's investment activity, not its operating one.

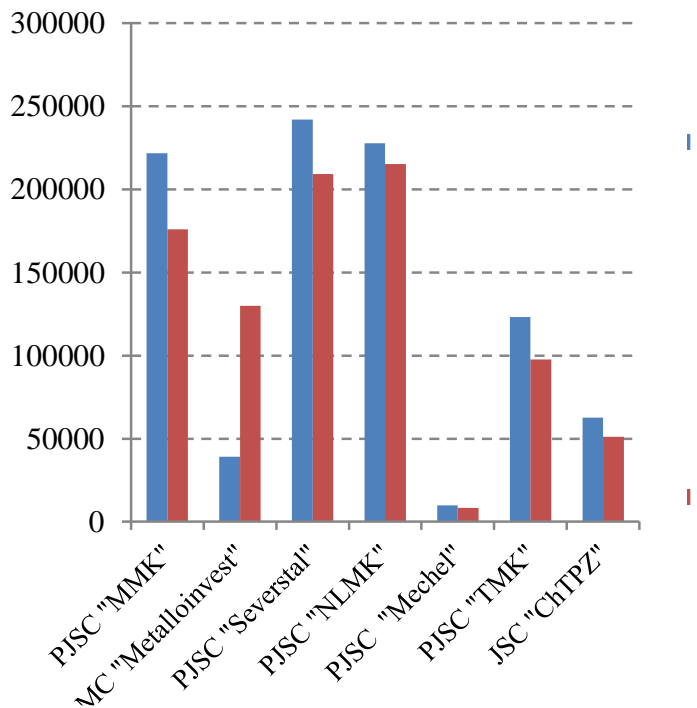

Figure 1: Revenues of Russian ferrous metallurgy holdings in the first half of 2019-2020.

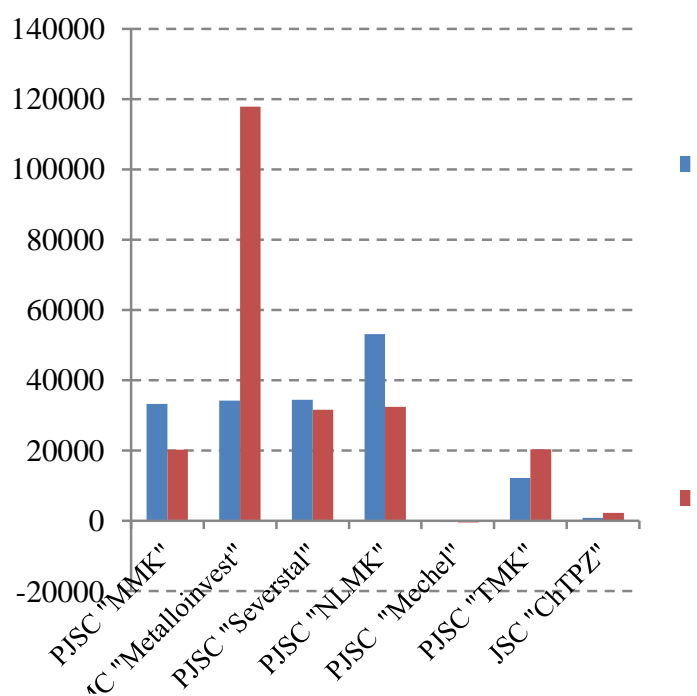

Figure 2: Net profit of Russian ferrous metallurgy holdings in the first half of 2019-2020.

With regard to the financial ratios characterizing the liquidity, solvency and financial independence of the surveyed companies, no unambiguous negative dynamics was revealed in the first half of 2020 as a result of the pandemic. Except for the fact that three holdings (JSC MC Metalloinvest, PJSC NLMK, PJSC Mechel) have reduced the share of sustainable sources of financing in Q1 2020 compared to Q4 2019. At the same time, however, most metallurgical holdings have actual values of financial 
ratios that do not correspond to the norms throughout the entire analyzed period (including the pre-crisis period), and this is especially evident in terms of current liquidity ratios, financial independence and financial stability.

\section{DISCUSSION OF FINDINGS}

Obviously, Russian steel companies are now facing an unprecedented threat - a significant drop in demand for iron ore and steel products due to the global and Russian economic downturn due to the COVID-19 pandemic in 2020 and its slowdown in the near term. The investigated industry, which is already in a rather unstable state (as evidenced by the analysis), was not ready for such a negative scenario.

In case of realization of pessimistic forecasts of the world and Russian economy development in the medium term, the authors identify the following probable trends in the functioning of Russian ferrous metallurgy companies:

- decrease in production of iron ore raw materials and metal products as a result of reduced demand on global and domestic markets;

- optimization of excess production capacities (conservation; sales; leasing, etc.);

- need for maximum reduction of production costs, resource and energy saving, and optimization of staff numbers;

- alienation of non-core assets (including social assets) as a result of their sale or transfer to municipalities free of charge;

- expanding the use of leasing schemes in solving the problem of reproduction of fixed assets;

- increase in import substitution (for fixed assets, spare parts, materials);

- limitation of the number of investment projects being implemented. Prevailing projects of reconstruction and modernization of existing fixed assets.

The above forecasted trends in the functioning of Russian metallurgical holdings serve as a serious substantiation of the need to improve and long-term ensure their financial stability, including through the implementation of the next set of measures:

1. Reducing the current level of debt burden through restructuring or refinancing of existing debt, finding provisions for partial repayment of debt obligations (collection of receivables; repayable lease; sale of noncore assets, etc.);

2. Increaing adaptive capacity to external shocks by diversifying markets, using scenario budgeting and flexible financial planning technologies, stochastic cash flow forecasting;

3. Cost reducing, optimization of business models, and business processes of metallurgical companies through the digitalization of their activities [14].

\section{CONCLUSIONS}

The results of the author's research devoted to the analysis of the impact of the COVID-19 coronavirus pandemic on the financial stability of Russian iron and steel companies demonstrated the extreme vulnerability of this industry to modern threats and medium-term consequences of the economic downturn. In this vein, increasing the financial stability of Russian metallurgical holdings, including through the implementation of the proposed set of measures, does not seem to be a possible scenario, but an objective necessity.

\section{REFERENCES}

[1] On the approval of the Strategy for the development of the ferrous metallurgy of Russia for 2014-2020 and for the future until 2030 and the Strategy for the Development of Non-Ferrous Metallurgy in Russia for 2014-2020 and for the future until 2030: order of the Ministry of Industry and Trade of Russia dated 05.05.2014 No. 839.

[2] N.I. Novikov, The role of ferrous metallurgy in the development of national and regional economies, N.I. Novikov, D.V. Podyapolsky, G.V. Novikova, Bulletin of Kemerovo State University, 2014, no. 2 (58), pp. 254-258.

[3] IMF World Economic Outlook, June 2020, Electronic resource.

[4] CRU Steel Sheet Products Market Outlook, 2020 Q3 Edition, July 2020, Electronic resource.

[5] Picture of business activity, Ministry of Economic Development of the Russian Federation, 2020, Electronic resource.

[6] Information on the socio-economic situation in Russia: January-May 2020. Federal State Statistics Service (Rosstat).

[7] Analytical review of the Metal Expert portal, July 2020, Electronic resource.

[8] Production of the main types of products of metallurgical production. Federal State Statistics Service (Rosstat).

[9] On the state and use of mineral resources of the Russian Federation in 2018: state report of the Ministry of Natural Resources of Russia, ed. E. A. Kiseleva. Moscow: FGBU "VIMS", 2019,424 p.

[10] L.F Shaybakova, Development of Ferrous Metallurgy in Russia: Trends, Special Features and Problems, Upravlenets, The Manager, 2017, № 5 (69), pp. 40-49.

[11] Overview of the iron and steel market in 2019 and Q1 2020: the Chinese factor. National Rating Agency, Electronic resource. 
[12] J.A. Dolgikh, J.E. Slepuhina. Development of methodological tools assessment of financial stability of enterprise, Advances in Social Science, Education and Humanities Research, vol. 240. Proceedings of the 2nd International Scientific conference on New

Industrialization: Global, national, regional dimension (SICNI 2018), 2019, pp. 146-150.

[13] Yu.A. Dolgikh, E.S. Panfilova, E.A. Smorodina. Digital Technologies in Ensuring Financial Strength of Russian Non-Ferrous Smelters, Advances in Economics, Business and Management Research, vol. 138.

Proceedings of the 2nd International Scientific and Practical Conference «Modern Management Trends and the Digital Economy: from Regional Development to Global Economic Growth» (MTDE 2020), 2020, pp. 787793. 